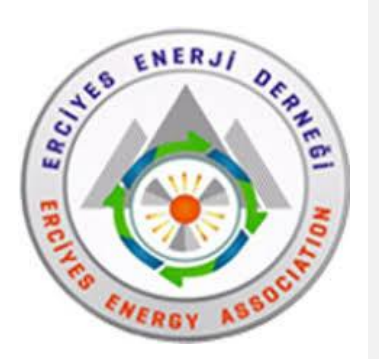

Energy, Environment and Storage

Journal Homepage: www.enenstrg.com

\title{
Numerical Investigation of the Effects of Window Height and Gas Thickness on Heat Transfer and Gas Flow in Double Pane Windows
}

\author{
Sebahattin ÜNALAN ${ }^{1 *}$, Evrim ÖZRAHAT ${ }^{2}$ \\ ${ }^{1 *}$ Department of Mechanical Engineering, Faculty of Engineering, Erciyes University,Melikgazi 38039, Kayseri, Türkiye \\ ${ }^{2}$ Bünyan Vocational School, Kayseri University, Bünyan 38600 Kayseri, Türkiye
}

\begin{abstract}
Double pane window is an effective way to reduce the heat loss from windows in buildings. There are many studies on the thermal performance of these window applications for different parameters such as optimum gap width, suitable filling fluid and different applications such as film coatings on panes to obtain different surface emissivity values or placing venetian blinds inside the gap, etc. These investigations are mostly based on the laminar flow assumption inside the gas gap between the two panes for the same window height. In this research, effect of the window height and gap width on the gas flow in the gap and heat transfer over double pane for three cities of Turkey representing different climates were numerically investigated with turbulent flow and ideal gas assumptions inside the gap for air and argon. In the calculations, natural convection for pane surface facing indoors and forced convection for pane surface facing outdoors was assumed as boundary condition. The numerical results shown that also the window height such as gap width has an effect on the heat transfer and gas flow of the double pane window. Thereby, the window height should be taken into consideration for determining the optimum gap width in the double pane window applications.
\end{abstract}

Keywords: Double pane window, energy saving, natural convection in rectangular cavity

Article History: Received:12.10.2020; Revised: 26.04.2021; Accepted:25.04.2021 Availableonline: 28.04.2021 Doi: https://doi.org/10.52924/ZMNV7482

\section{INTRODUCTION}

Decreasing the energy demand of buildings is a hot topic of science nowadays. The windows used for utilizing the day light are thermal holes of the building both in winter and summer times. Double pane window is an efficient way to reduce the heat loss from indoors in winter. It consists of two glass panes and $\not d$ filling gap commonly filled by air between the panes. Optimum gas thickness or width value (L) of this gap is investigated in literature for a long time for different parameters.

The heat transfer through a double-pane window is analyzed numerically by a finite difference technique [1]. The thermally optimum air-layer thickness between the two panes for different climates is determined. Four different cities of Turkey, representing different climate conditions are considered: Ankara, Antalya, Kars and Trabzon. The height of the window, $\mathrm{H}$ is chosen $80 \mathrm{~cm}$. The effect of airlayer thickness varies between $\mathrm{L}=3$ and $40 \mathrm{~mm}$ on the average Nusselt Number and the heat flux through the inner pane. It was shown that energy losses through the doublepane windows can be considerably reduced by optimizing the thickness of air layer. Instead of assuming the panes as isothermal surfaces [1], much more realistic boundary conditions considered for panes for the same window. It was shown that filling the space between the glass panes with a gas having a lower thermal conductivity instead of air reduces the insulating value of the window [2].

The optimum air layer thickness of double-glazed windows is determined using the degree day method. Calculations were obtained for İskenderun, Kocaeli, Ankara and Ardahan which are in different climate zones of Turkey. The results showed that the optimum air layer thickness varies between $\mathrm{L}=12$ and $15 \mathrm{~mm}$ depending on the climate zone, fuel type and base temperature [3]. Also a thermo economical optimization of multiple pane window applications for İskenderun, İzmir, Kocaeli, Sinop, Malatya, Ankara, Van and Ardahan cities which are located in different climatic regions of Turkey was carried out using the degree-day method. The results showed that the optimum number of panes in Turkey varies between 2 and 4 depending on the climate zone and fuel type [4].

Fluid flow and heat transfer in double, triple and quadruple pane windows having height of $\mathrm{H}=100 \mathrm{~cm}$ were investigated numerically. About 50\% or 67\% of energy savings could be made if the double pane window is replaced by triple or quadruple pane windows, respectively. 
[5]. A parametric study was carried out numerically to investigate fluid flow and heat transfer characteristics in double, triple and quadruple pane windows (having height of $\mathrm{H}=100 \mathrm{~cm}$ ) considering various gap widths together with different emissivity coatings. Computations were performed for both air-filled and argon-filled windows. The results showed that the most reasonable gap width is $12 \mathrm{~mm}$ for all cases considered in this study [6]. The regularities of heat transfer through a triple-pane glass window with air and argon fillings have been investigated by the method of numerical modeling. The thermal resistances of the triplepane window (having height of $\mathrm{H}=108 \mathrm{~cm}$ ) as functions of the gas-interlayer thickness and of temperature on the window's exterior surface have been found [7].

Innovative solutions were also proposed for double pane windows and water-flow double-pane window design is an innovative concept that involves a controlled flow of water within the cavity between the two glass panes [8]. As the heat extracted by flowing water is much higher than by ventilating air, the room heat gain can be reduced considerably and at the same time, the window can serve as a water pre-heating device. The integrative thermal performance of a water-flow absorbing window having height of $\mathrm{H}=125 \mathrm{~cm}$ was compared with the conventional single and double pane absorptive glazing [9]. Another innovative solution proposed is supply air window. The supply air window is a variation of the multiple pane window in which air is pulled in from outside and is heated through conduction, convection and radiation in the cavity. An experimental rig was designed, constructed and used to measure the flow field and temperatures with the aim of validating the CFD models with a window having $99 \mathrm{~cm}$ height [10].

A two-dimensional numerical analysis for thermal control strategies on potential energy savings in a double-pane window integrated with see-through a-Si photovoltaic (PV) cells with low-emittance (low-e) coatings was investigated. Aspect ratio (height/gas width ratio, H/L) of window was given as 10. [11]. A reference window with empty gap was compared with windows where the gap contains fins arranged in such a way as to reduce heat transfer. In this study, the window height was chosen as $\mathrm{H}=49.6 \mathrm{~cm}$. Convective heat transfer inside the gap of double glazed windows was studied numerically using a commercial CFD code (FLUENT v6.3), for different Rayleigh Numbers and aspect ratios [12].

The studies mentioned above for optimum gap width value or air-layer thickness were performed for only one window height value. Studied window height values in literature are varying between $\mathrm{H}=49 \mathrm{~cm}$ and $125 \mathrm{~cm}$. Effect of window height or aspect ratio (height/gas thickness, H/L ratio) on determining the optimum gap was not considered in literature. In the previous studies, constant temperature

Table 1 Design winter temperatures and atmospheric pressures for the cities considered in this study

\begin{tabular}{|l|c|c|c|}
\hline City & Tout $\left[{ }^{\circ} \mathrm{C}\right]$ & $\Delta \mathrm{T}=$ Tin-Tout $\left[{ }^{\circ} \mathrm{C}\right]$ & $\mathrm{P}[\mathrm{Pa}]$ \\
\hline Antalya & 3 & 17 & 100800 \\
\hline Kayseri & -15 & 35 & 89095 \\
\hline Kars & -27 & 47 & 81980 \\
\hline
\end{tabular}

boundary condition (uniform temperature distribution) or forced convective boundary condition was used as boundary condition. Constant temperature boundary condition or uniform temperature distribution assumption on pane surface would not be a realistic approach in terms of naturel convection realization in the air gap, because the air circulation between the panes is occurred by the temperature gradient on the pane surfaces [6]. However, this problem was not investigated in detail as a function of the pane height in literature. Consequently, in order to see the effect of window height on heat transfer, double pane window was modeled numerically for different window heights. For a realistic approach, while boundary condition on the inner pane surface side of indoor was taken as naturel convective, the boundary condition on the outer pane surface by outdoor was selected as forced convection. Thus, the convective effect caused by the probable wind was taken into consideration. In addition, the flow is assumed to be turbulent rather than laminar flow assumption in the above studies. The numerical analyses are performed for three different cities Antalya, Kayseri and Kars of Turkey representing different outdoor climate conditions.

\section{MATERIALS AND METHODS}

\subsection{Problem Description And Numerical Method}

In this study, flow and heat transfer characteristics of double pane window for various gas thicknesses with different heights was investigated numerically. Schematic representation of the double pane window is shown in Figure 1. Panes are $4 \mathrm{~mm}$ ordinary glass. Indoor temperature (Tin) is assumed constant as Tin $=20{ }^{\circ} \mathrm{C}$ for thermal comfort. Outdoor temperature (Tout) values are assumed equal to the winter design temperatures of each city as stated in Table 1 . Operation pressure (P) was set as the atmospheric pressure values for the cities altitude values as stated in Table 1 . In addition, also temperature difference ( $\Delta \mathrm{T}=\mathrm{Tin}$-Tout) between indoors and outdoors can be seen in Table 1.

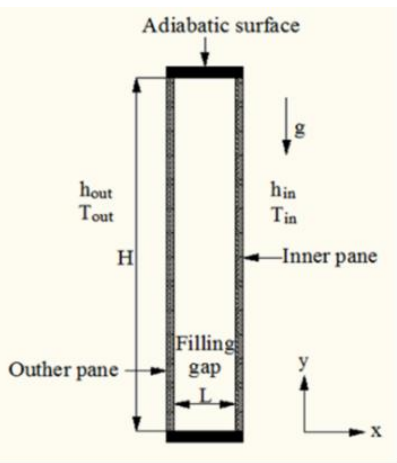

Fig. 1. Schematic representation of the double pane window

For numerical and parametric calculations, thermo-physical properties (specific heat, dynamic viscosity and thermal conductivity) of air were taken as fourth degree polynomial $(=\mathrm{a}+\mathrm{bT}+\mathrm{cT} 2+\mathrm{dT} 3+\mathrm{eT} 4)$ as a function of temperature $(\mathrm{T}$ $[\mathrm{K}])$. The $\mathrm{a}, \mathrm{b}, \mathrm{c}, \mathrm{d}$ and e constants of polynomial equation can be seen Table 2. The thermo-physical properties (specific heat, dynamic viscosity and thermal conductivity) of argon were taken as; $\mathrm{Cp}=519 \mathrm{~J} / \mathrm{kgK}, \mu=(0.066 \mathrm{~T}$ 
$+2.97) \cdot 10-6$ Pa.s, and $\mathrm{k}=(0.0516 \mathrm{~T}+2.3) \cdot 10-3 \mathrm{~W} / \mathrm{mK}$, respectively [7,13]. For calculation of flow and heat transfer between two panes, air and argon were treated as incompressible ideal gas.

Table 2 The constants for thermo-physical properties of air

\begin{tabular}{|c|c|c|c|}
\hline & $\mathrm{Cp}(\mathrm{T})$ & $\mu(\mathrm{T})$ & \multicolumn{1}{c|}{$\mathrm{k}(\mathrm{T})$} \\
\hline $\mathrm{a}$ & $1,03 \mathrm{E}+03$ & $1.660072 \mathrm{E}-06$ & $2.064614 \mathrm{E}-03$ \\
\hline $\mathrm{b}$ & $-2.989620 \mathrm{E}-01$ & $6.693351 \mathrm{E}-08$ & $8.731414 \mathrm{E}-05$ \\
\hline c & $8.350206 \mathrm{E}-04$ & $-4.120350 \mathrm{E}-11$ & $-2.641003 \mathrm{E}-0$ \\
\hline d & $-5.536863 \mathrm{E}-07$ & $1.728613 \mathrm{E}-14$ & $4.008917 \mathrm{E}-12$ \\
\hline e & $1.239482 \mathrm{E}-10$ & $-2.921590 \mathrm{E}-18$ & 0 \\
\hline
\end{tabular}

The forced convection heat transfer coefficient (hout) is selected constant as $15 \mathrm{~W} / \mathrm{m} 2 \mathrm{~K}$. As stated in Ref.[2] changing this value from 15 to $30 \mathrm{~W} / \mathrm{m} 2 \mathrm{~K}$ did not influence a lot, just suggesting a negligible $2.6 \%$ increase in heat flux and no considerable effect on the curves of optimum gap value. The natural convection heat transfer coefficient (hin) is calculated by Average Nusselt Number ( ), Prandtl Number (Pr) and Rayleigh Number (Ra) by the following correlations determined for heat transfer from hot vertical surfaces according to Ref [14] :

$$
\begin{aligned}
& h_{\text {in }}=\frac{k \overline{N u}}{H} \\
& \overline{N u}=\left\{0.825+\frac{0.387[R a]^{1 / 6}}{\left[1+(0.492 / \operatorname{Pr})^{9 / 16}\right]^{8 / 27}}\right\}^{2} \\
& R a=\frac{\rho \beta \Delta T H^{3}}{v \alpha}, \quad \operatorname{Pr}=\frac{v}{\alpha}, \quad v=\frac{\mu}{\rho}, \\
& T_{f}=\frac{T_{s}+T_{i n}}{2}, \quad \beta=\frac{1}{T_{f}}
\end{aligned}
$$

For the calculation by means of the polynomial function $(=\mathrm{a}+\mathrm{bT}+\mathrm{cT} 2+\mathrm{dT} 3+\mathrm{eT} 4)$ of thermal conductivity $(\mathrm{k})$, thermal diffusite $(\alpha)$, density $(\rho)$ and kinematic viscosity $(v)$ values of the indoor air in the above equations, the average value (Tf) of inner pane surface temperature (Ts) on the surface facing indoors and indoor temperature (Tin) was used. Thermo physical properties (density, specific heat, thermal conductivity) of the pane are taken as $\rho=2700$ $\mathrm{kg} / \mathrm{m}^{3}, \mathrm{Cp}=840 \mathrm{~J} / \mathrm{kgK}$ and $\mathrm{k}=0.78 \mathrm{~W} / \mathrm{mK}$, respectively.

Two-dimensional model of double pane window was built and mesh structure was created in GAMBIT software. It was imported to ANSYS FLUENT Version 15 [15] which was used for numerical simulation of air flow and heat transfer in the double pane window. Double pane windows vertical inner and outer pane surfaces were set as convective heat transfer wall boundaries. Horizontal walls are defined as adiabatic walls with zero heat flux. The flow is assumed to be turbulent and steady. The RNG k-epsilon model is selected with enhanced wall treatment. A comparative numerical study with other turbulence models was conducted by the authors [16]. Results of the numerical study of the different turbulence models are compared with an empirical equation in literature [14] and RNG k-epsilon model with enhanced wall treatment is found to be the most suitable turbulence model for this problem. The SIMPLE algorithm was used for the velocity-pressure coupled relations among the governing equations. The convergence criterion for continuity equation and energy equation was 10-5 and 10-6, respectively.

According to the Eqs.1-3, the natural convection heat transfer coefficient (hin) values are varied by the surface temperature on the surface facing indoors (Ts). Therefore, the surface temperature should be known. However, this surface temperature value will be determined by the FLUENT calculations. Thus, for predicting the real value of hin the calculation loop in Figure 2 is considered.

\subsection{Code Validation}

In order to validate the results a numerical study was performed for a rectangular cavity of $\mathrm{H} / \mathrm{L}=4(\mathrm{H}=40 \mathrm{~cm}$, $\mathrm{L}=10 \mathrm{~cm}$ ). This rectangular cavity filled with air is heated from vertical one side and cooled from the other side with horizontal adiabatic walls. The numerical simulation results with the RNG k-epsilon model and the enhanced wall treatment were compared with the empirical correlations of the average Nusselt Number from literature [14] which can be seen in Table 3. These correlations are:

$$
\begin{aligned}
& N u_{L}=0.22\left(\frac{P r}{0.2+P r} R a_{L}\right)^{0.28}\left(\frac{H}{L}\right)^{-1 / 4} \\
& {\left[\begin{array}{c}
2<\frac{H}{L}<10 \\
P r<10^{5} \\
10^{3}<R a_{L}<10^{10}
\end{array}\right]}
\end{aligned}
$$




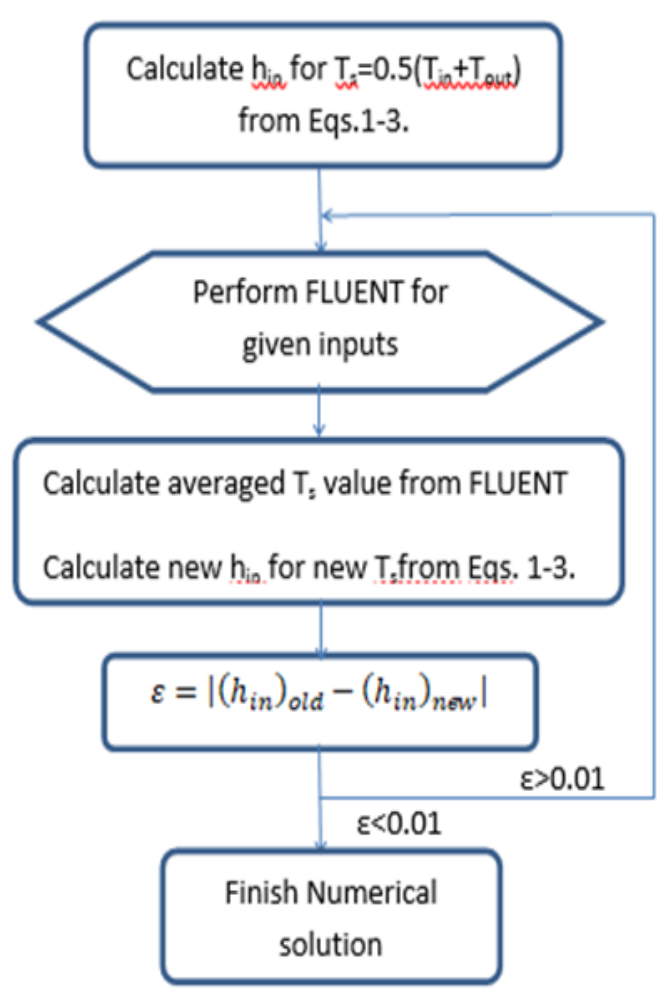

Fig. 2. Calculation Loop of hin value

It was observed that the agreement of the pre sent solution and empirical correlation is excellent and the code is valid for numerical simulation with the selected numerical parameters.

Table 3 Comparison of the Nusselt Number for various Rayleigh Numbers

\begin{tabular}{|c|c|c|c|c|}
\hline $\begin{array}{c}\mathrm{H} / \\
\mathrm{L}\end{array}$ & $\mathrm{Ra}$ & Present Study & $\begin{array}{c}\text { Ref.[12 } \\
]\end{array}$ & $\begin{array}{c}\text { Error } \\
\%\end{array}$ \\
\hline 4 & $1 \times 106$ & 7.04 & 7.01 & 0.004 \\
\hline 4 & $1 \times 107$ & 13.21 & 13.24 & 0.002 \\
\hline
\end{tabular}

\subsection{Mesh Independency}

The solutions are performed for different mesh sizes for the windows which has the highest aspect ratio (=533) as 1600 $\mathrm{mm} / 3 \mathrm{~mm}$ and the smallest aspect ratio $(=10)$ as $400 \mathrm{~mm} / 40$ $\mathrm{mm}$ for Kayseri city. Meshing was performed with quadrilateral mesh elements with map option that creates a regular structured grid in GAMBIT. The results are given in Table 4. Both for two different gaps $3 \mathrm{~mm}$ and $40 \mathrm{~mm}$, the difference in total heat flux (q) is not considerable for different mesh sizes. In terms of cost and accuracy, a uniform mesh size of $1 \mathrm{~mm}$ is adopted for solutions.

Table 4 The q [W] values for various grid sizes

\begin{tabular}{|c|c|c|}
\hline Grid size[mm] & $\begin{array}{c}\mathrm{H}=40 \mathrm{~cm}, \\
\mathrm{~L}=40 \mathrm{~mm}\end{array}$ & $\begin{array}{c}\mathrm{H}=160 \mathrm{~cm}, \\
\mathrm{~L}=3 \mathrm{~mm}\end{array}$ \\
\hline 2 & 47.10 & - \\
\hline 1 & 46.42 & 75.73 \\
\hline 0.5 & 46.07 & 75.73 \\
\hline 0.25 & 46.00 & 75.73 \\
\hline
\end{tabular}

\section{RESULTS}

The results obtained from the numerical solution is presented and discussed in this section. The streamlines of the highest gap width value of $40 \mathrm{~mm}$ was presented for various cities for $40 \mathrm{~cm}$ air filled window (Figure 3) and 40 $\mathrm{cm}$ argon filled window (Figure 4). It can be seen that the flow is one circulation region as the fluid rises along the hot side and falls down along the cold side for all investigated window heights, gap widths, fluid types and for all cities.
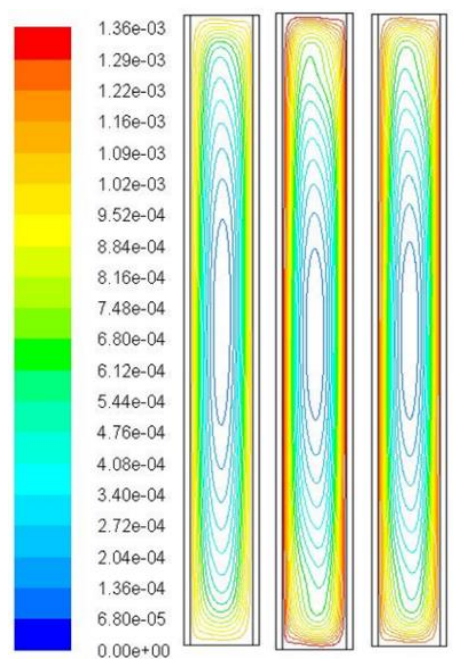

(a) (b) (c)

Fig. 3. Streamlines at $\mathrm{L}=40 \mathrm{~mm}, \mathrm{H}=40 \mathrm{~cm}$ for air filled window a) Antalya, b) Kayseri, c) Kars 


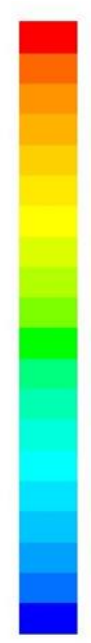

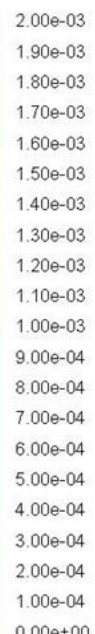

$0.000+00$ (a) (b) (c)

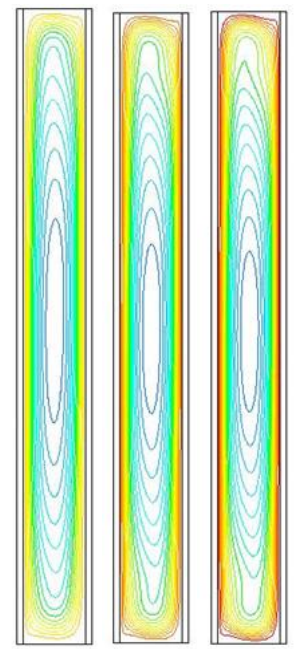

Fig. 4. Streamlines at $\mathrm{L}=40 \mathrm{~mm}, \mathrm{H}=40 \mathrm{~cm}$ for argon filled window a) Antalya, b) Kayseri, c) Kars

Velocity profiles at $\mathrm{y}=0.5 \mathrm{H}$ for the highest and smallest window height and the examined cities are shown in Figure 5 and Figure 6 for air and argon filled windows, respectively. The obtained velocity profiles are similar curves to each other for all cases. Generally, increasing the window height caused higher fluid flow velocity for both air and argon. The velocities with argon are higher slightly than velocities reached with air. As expected, the low design winter temperatures cause higher gas velocities. Thereby, the velocity values are the highest for Kars city which has the lower design winter temperature as $0.17 \mathrm{~m} / \mathrm{s}$ and $0.18 \mathrm{~m} / \mathrm{s}$ in $160 \mathrm{~cm}$ window with $40 \mathrm{~mm}$ argon and air filled gap, respectively. The lowest values are obtained for Antalya city which has the higher design winter temperature as $0.08 \mathrm{~m} / \mathrm{s}$ and $0.09 \mathrm{~m} / \mathrm{s}$ in $40 \mathrm{~cm}$ window with $40 \mathrm{~mm}$ argon and air filled gap, respectively. For Antalya city, air flow velocity is increased $37.5 \%$ for $\mathrm{H}=160 \mathrm{~cm}$ window compared with $\mathrm{H}=40 \mathrm{~cm}$ window for $\mathrm{L}=40 \mathrm{~mm}$ air filled gap. Air flow velocity was increased $25 \%$ for Kayseri and $21.4 \%$ for Kars by increasing the window height from $40 \mathrm{~cm}$ to $160 \mathrm{~cm}$ for air filled window. For Argon filled window by increasing the window height from $40 \mathrm{~cm}$ to $160 \mathrm{~cm}$, these values are increased 33\%, 23\% and $20 \%$ for Antalya, Kayseri and Kars, respectively.

Longitudinal temperature variation on surfaces facing indoor and outdoor of the pane versus the pane height can be seen in Figure 7 and Figure 8, for air and argon filled windows, respectively. These figures are important in terms of the reliability of the results providing with constant (uniform) temperature boundary condition assumption in the literature. According to these figures, at lower $\mathrm{L}$ values (3 and $6 \mathrm{~mm}$ ), the longitudinal temperature variation is nearly constant along the pane (almost uniform temperature distribution). However, as expected, there is a temperature difference between the bottom and top of the pane similar with Ref.6. The differences on the outdoor surface is lower than those the indoors surfaces. In addition, the difference values reached for Kars city with low design temperature are higher than those for Antalya city with high design temperature. Namely, while the highest difference occurs for indoors surface of Kars city, the lowest difference occurs for outdoors surface of Antalya city. The temperature difference values for other cases are between these highest and lowest values. For $\mathrm{L}=3 \mathrm{~mm}$ and $\mathrm{H}=40 \mathrm{~cm}$, the highest and lowest temperature values between the bottom and top of the pane are 0.25 and $0.03^{\circ} \mathrm{C}$ with air and 0.34 and $0.03^{\circ} \mathrm{C}$ with argon, respectively. Also for $\mathrm{L}=6$ $\mathrm{mm}$, the highest and lowest temperature values increase to 2.84 and $0.28^{\circ} \mathrm{C}$ with air and 3.4 and $0.32^{\circ} \mathrm{C}$ with argon, respectively. Also for $\mathrm{L}=15 \mathrm{~mm}$ and $\mathrm{L}=40 \mathrm{~mm}$ (in parentheses), the highest and lowest temperature values are about $18.67(18,52)$ and $3.05(3.35){ }^{\circ} \mathrm{C}$ with air and 17.59 (17.67) and $2.68(2.83){ }^{\circ} \mathrm{C}$ with argon, respectively. The temperature differences reached with $\mathrm{H}=160 \mathrm{~cm}$ and $\mathrm{L}=3$ $6 \mathrm{~mm}$ are nearly those of temperature differences reached with $\mathrm{H}=40 \mathrm{~cm}$. However, the difference values calculated for $\mathrm{L}>6 \mathrm{~mm}$ higher than those of temperature differences reached with $\mathrm{H}=40 \mathrm{~cm}$. The difference with $\mathrm{L}=40 \mathrm{~mm}$ and $\mathrm{H}=160$ for air and argon increase to 22.18 and $20.86{ }^{\circ} \mathrm{C}$, respectively. Consequently, for $\mathrm{L}>6 \mathrm{~mm}$, the temperature distribution was changed from uniform distribution to nonuniform distribution. As expected, lower design temperature occurs at the bottom region of the pane and higher temperatures occur at the upper region. Air circulation at the gap region was caused by this temperature difference. According to these figures, it was concluded that the calculations with constant temperature boundary condition assumption along the pane surface is not realistic for $\mathrm{L}>6 \mathrm{~mm}$. Another result is that, as expected, while the temperature values at the outer pane surfaces are decreasing, temperature values at the inner pane surfaces are increasing with increasing $\mathrm{L}$ values. Namely, the temperature difference between inner and outer pane surfaces increases as a function of $L$ thickness.

As the mentioned in the previous section, for the natural convection or the natural convection heat transfer coefficient (hin) calculations inside the room, average of the surface temperature value of surface facing indoors of inner pane was used. For that purpose, the surface average values of the curves of the Figure 7 and Figure 8 were calculated by FLUENT. Thus, the variation of the calculated average temperature values versus $L$ was traced. The averaged temperature (Tinpane) value of the inner pane surface facing indoors and the averaged temperature (Toutpane) value of the outer pane surface facing outdoors for air filled and argon filled window of Kars city can be seen in Figure 9 and Figure 10, respectively. As the gap width $\mathrm{L}$ increases, the inner pane surface temperature increases rapidly for $\mathrm{L}<15 \mathrm{~mm}$ both for air and argon. For $\mathrm{L}>15 \mathrm{~mm}$, the temperature curves show asymptotical behavior. However, the outer pane surface temperature curves exhibited a converse characteristic behavior. As the gap width increases outer pane surface temperature decreases up to $\mathrm{L}<15 \mathrm{~mm}$. In addition, the calculated temperatures for inner and outer surfaces decrease and increase slightly for $\mathrm{H}<80 \mathrm{~cm}$, respectively. Obtained values are higher for argon compared with air. 

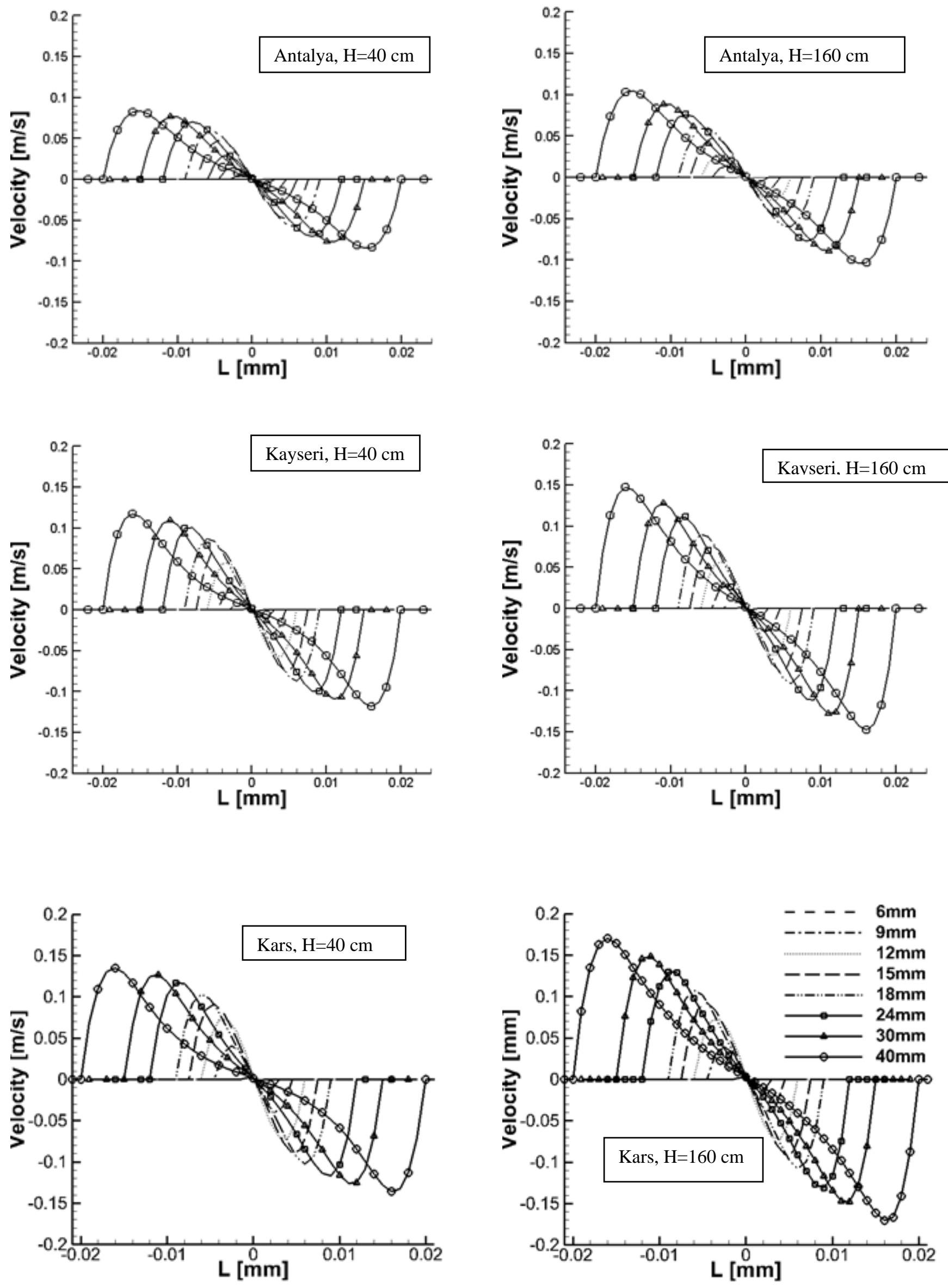

Fig. 5. Velocity profiles of air filled window for different cities for various window heights (at $\mathrm{y}=0.5 \mathrm{H}$ ). 

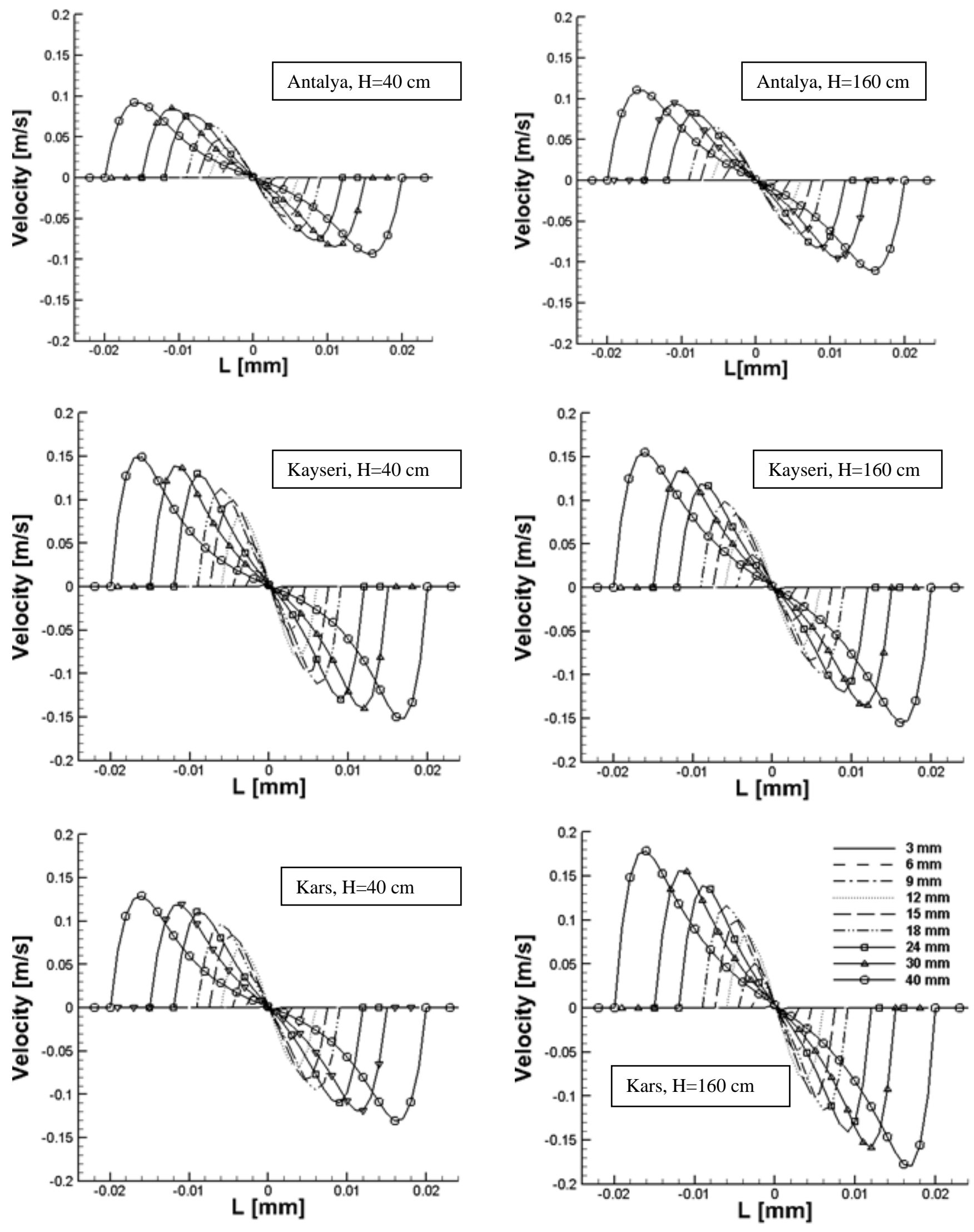

Fig. 6. Velocity profiles of argon filled window for different cities for various window heights (at $y=0.5 \mathrm{H}$ ) 

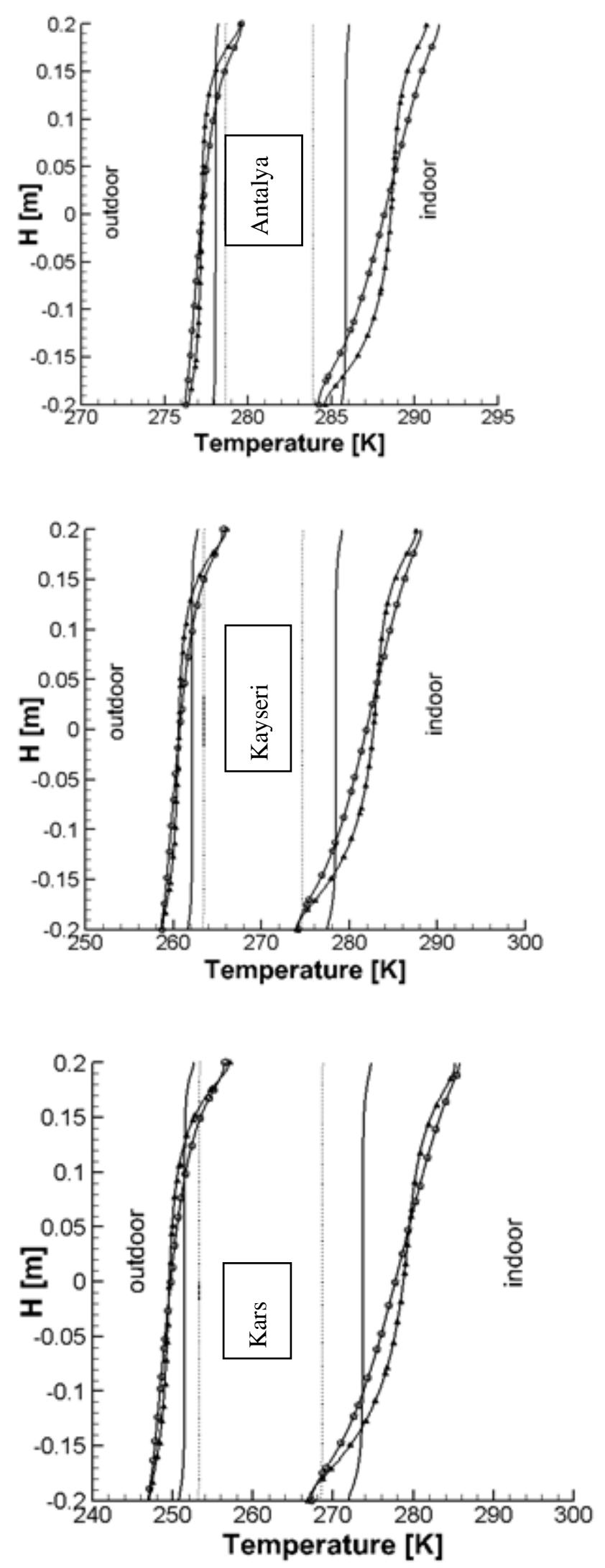

(a)

Fig. 7. Longitudional temperature profiles on inner (a) and outer (b) pane surfaces for air filled window)
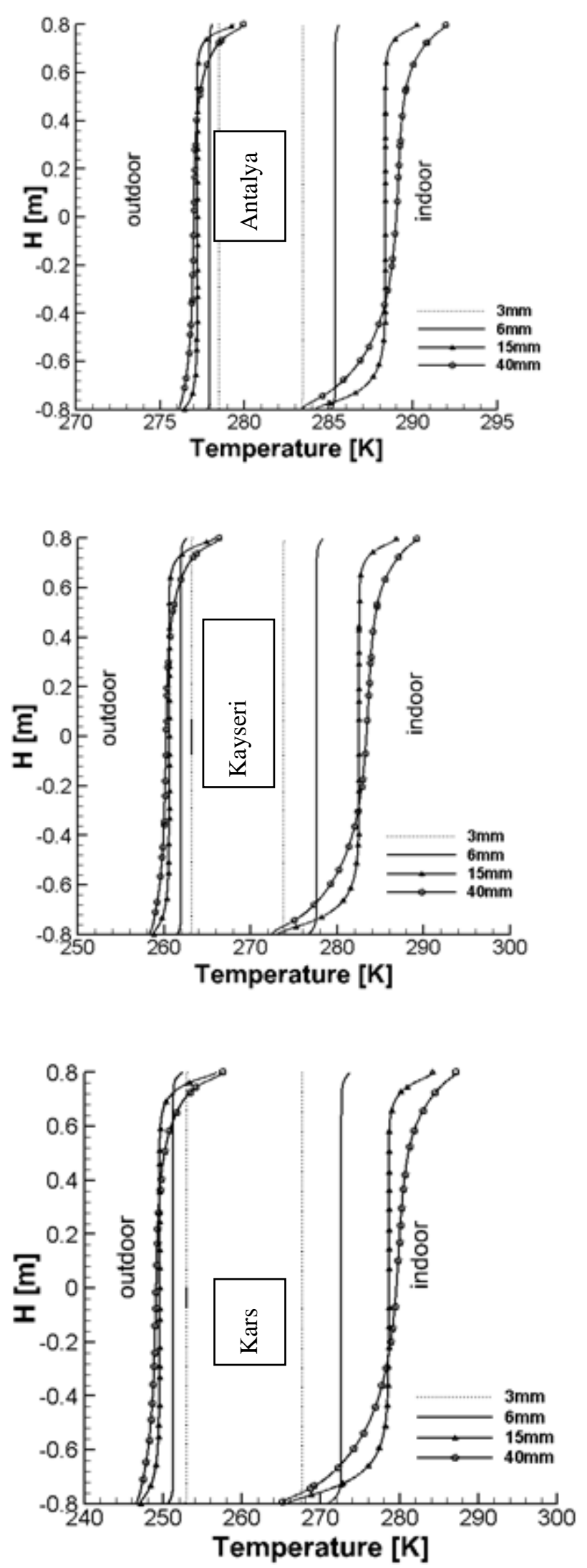

(b) 

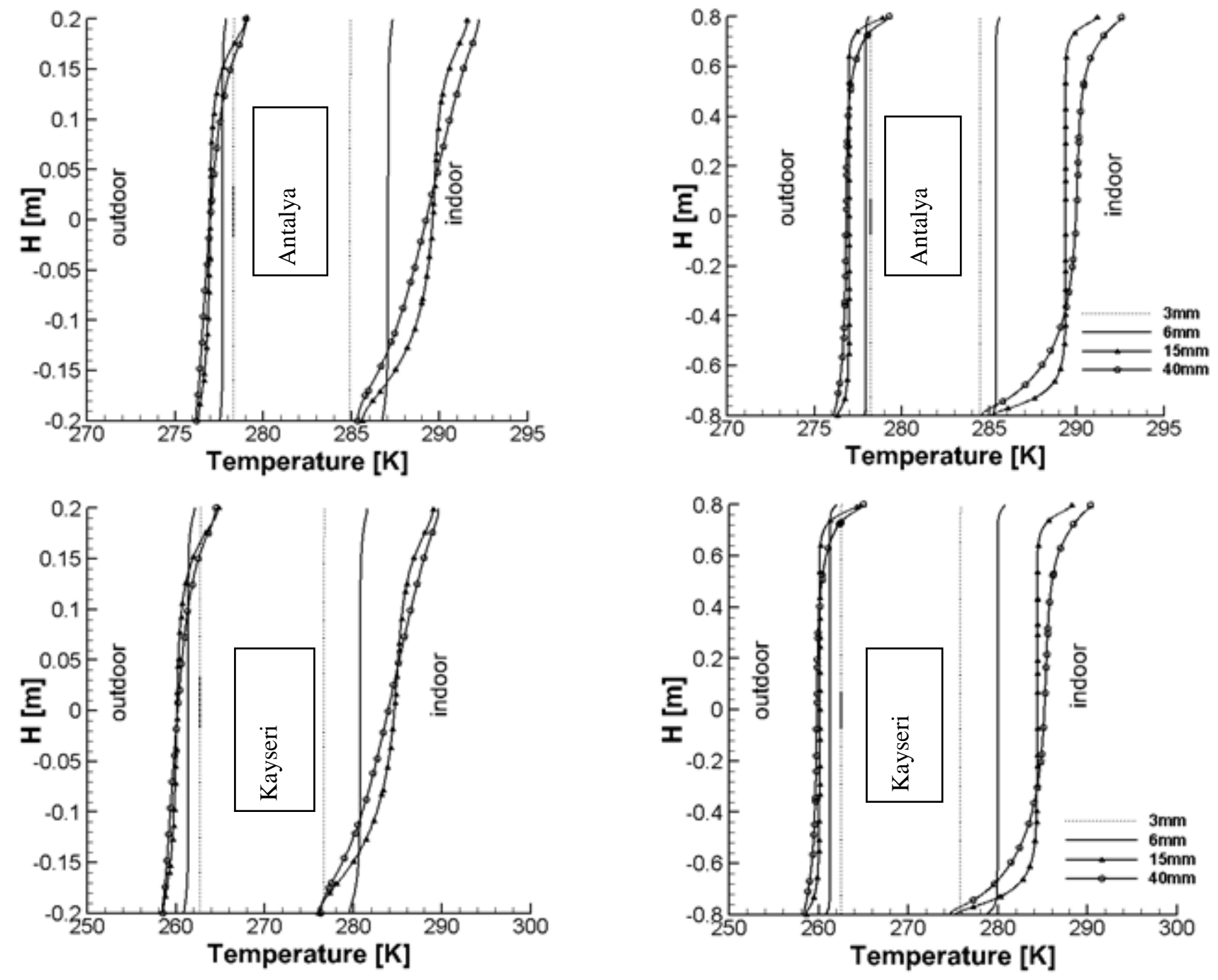

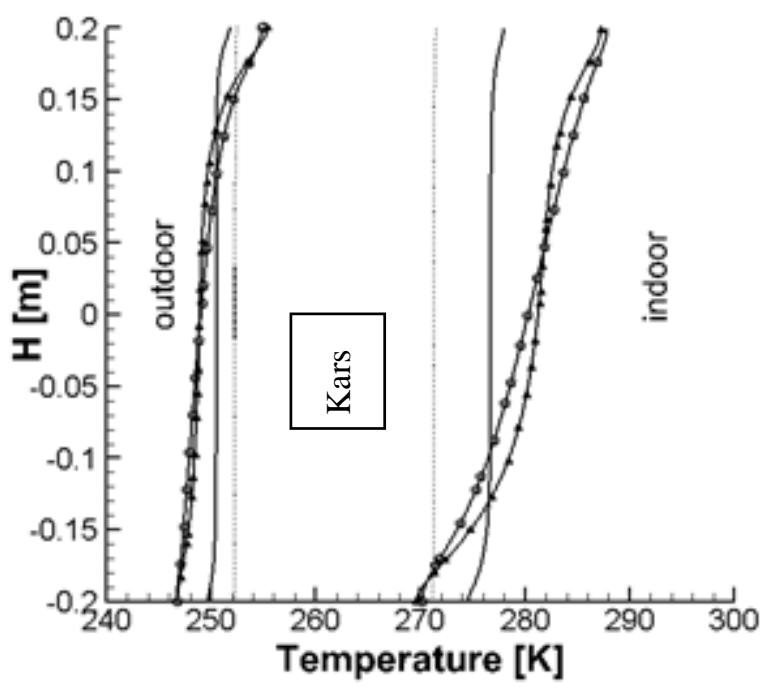

(a)

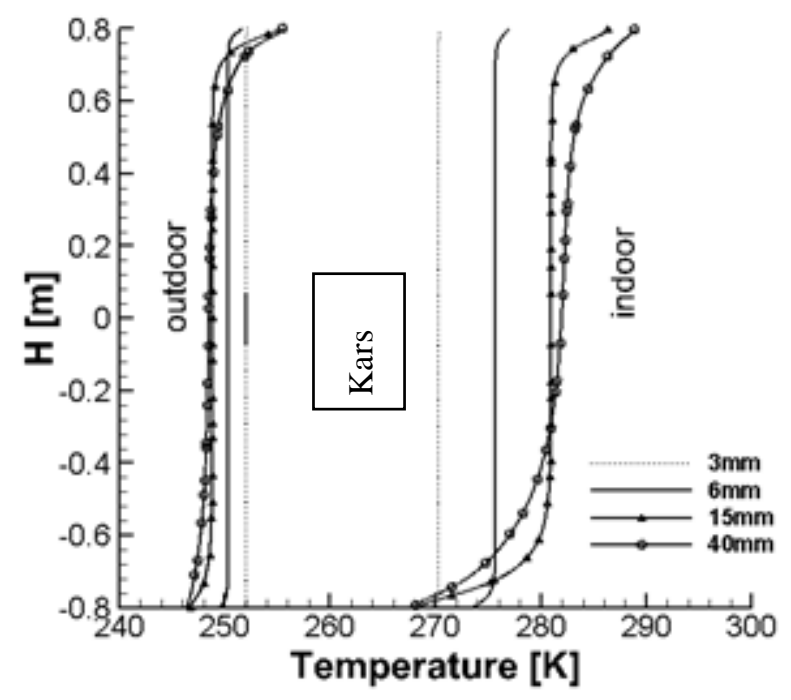

(b)

Fig. 8. Longitudional temperature profiles on inner (a) and outer (b) pane surfaces for argon filled window. 


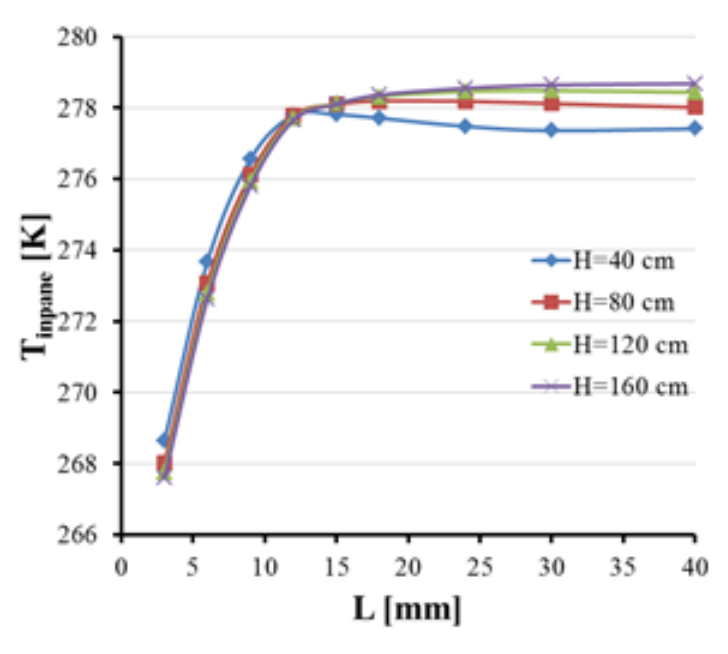

(a)

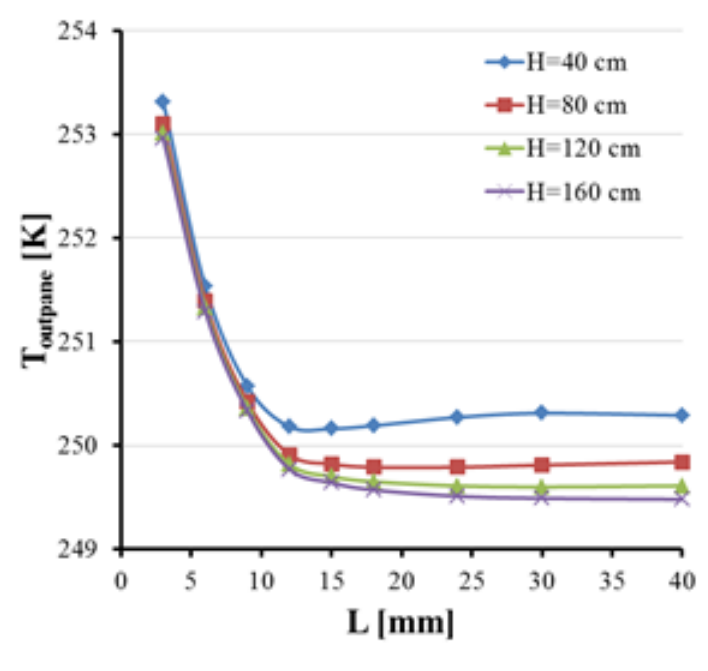

(b)

Fig. 9. The average temperature values versus gap width for air filled window for Kars city on a)inner pane surface, b) outer pane surface

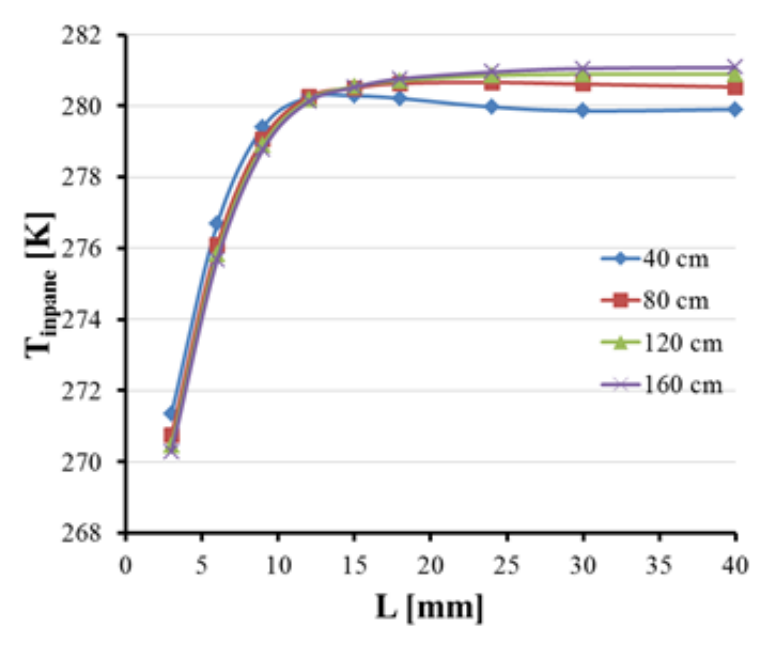

(a)

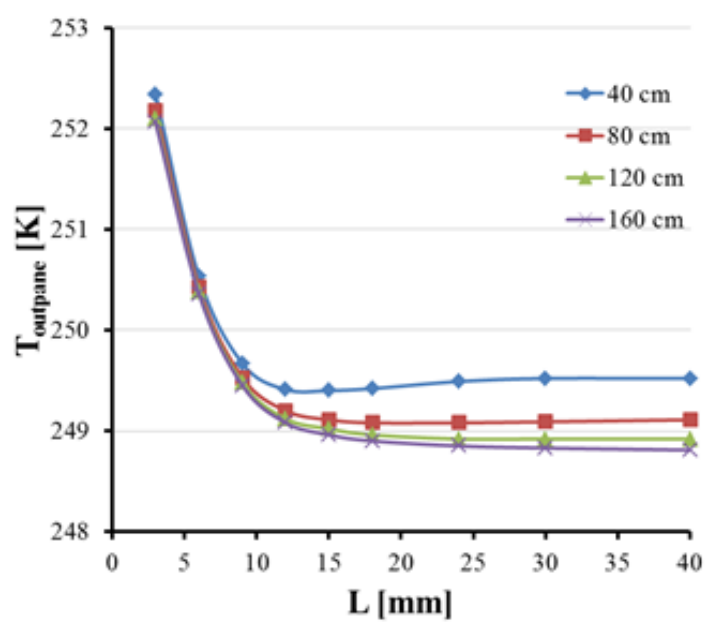

(b)

Fig. 10. The average temperature values versus gap width for argon filled window for Kars city on a)inner pane surface, b) outer pane surface

The most important parameter for this study is the heat flux $\mathrm{q}^{\prime \prime}$ passing through the system. For energy saving or the lowest heat lost, the heat transfer from the two panes and air gap is desired to be at minimum level. Variation of the heat flux values versus gap width value (L) for the investigated cases are given in Figure 11 and Figure 12 for air and argon, respectively. Generally, for $\mathrm{L}<20 \mathrm{~mm}$ as the $\mathrm{L}$ increases, q" value decreases rapidly. For $\mathrm{L}>20 \mathrm{~mm}$ it stays nearly constant with an asymptotical behavior. For small $\mathrm{H}$ values $(\mathrm{H}<80 \mathrm{~cm}) \mathrm{q}^{\prime \prime}$ has a minimum value at a certain $\mathrm{L}$ (critical) value. These critical values are around 16,14 and $13 \mathrm{~mm}$ for $\mathrm{H}=40 \mathrm{~cm}$, for Antalya $\left(\Delta \mathrm{T}=19{ }^{\circ} \mathrm{C}\right.$, temperature difference between the indoors and outdoors), Kayseri $\left(\Delta \mathrm{T}=37^{\circ} \mathrm{C}\right)$ and $\operatorname{Kars}\left(\Delta \mathrm{T}=49^{\circ} \mathrm{C}\right)$, respectively. According to these results, critical $\mathrm{L}$ values are decreasing by increasing $\Delta \mathrm{T}$ values. For $\mathrm{H}=80 \mathrm{~cm}$, these values are increasing to $\approx 20-25 \mathrm{~mm}$. For $\mathrm{H}>80 \mathrm{~cm}$, there is not a critical $L$ value. With increasing the $L$ values, $q^{\prime \prime}$ values either stays constant or a small decrease was occurred. These results indicate that critical $L$ values for these windows are at higher $L$ values than the values considered in this study. Another important result is that, q" heat flux values are decreased by increasing $\mathrm{H}$ values. These figures also showed that $\mathrm{H}$ value has a considerable effect on the $\mathrm{q}^{\prime \prime}$ results. Filling the gap with argon instead of air does not changed the behavior of the heat flux curves but caused lower heat flux values than air's values. The heat flux values with argon decrease between $12-20 \%$ according to air for the investigated cities and all cases in terms of energy saving. As a function of the $\mathrm{L}$, the decrement can be seen in Figure 12 for Kars city. Obtained values of other cities are nearly the same as Figure 13. The figure shows that the decrement caused by argon filling will be affected by height of the pane $\mathrm{H}$. 
Energy, Environment and Storage (2021) 01-01-13-25

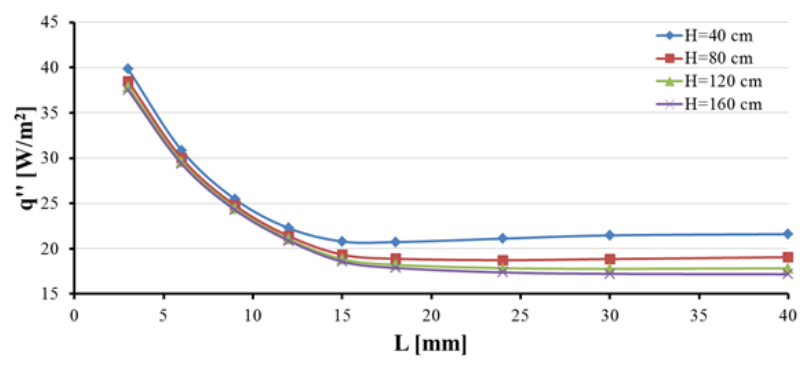

a) Antalya

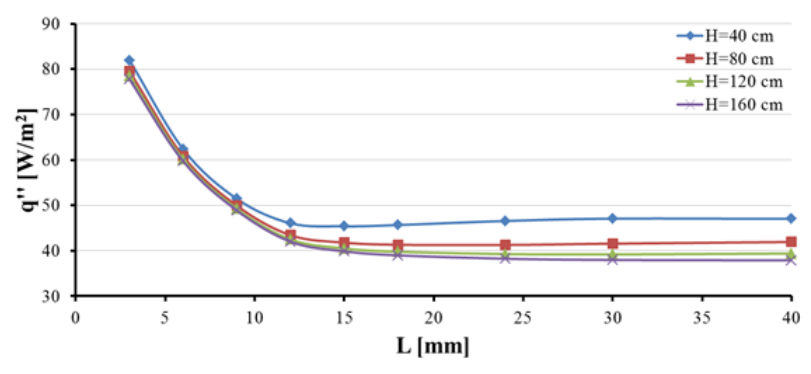

b) Kayseri

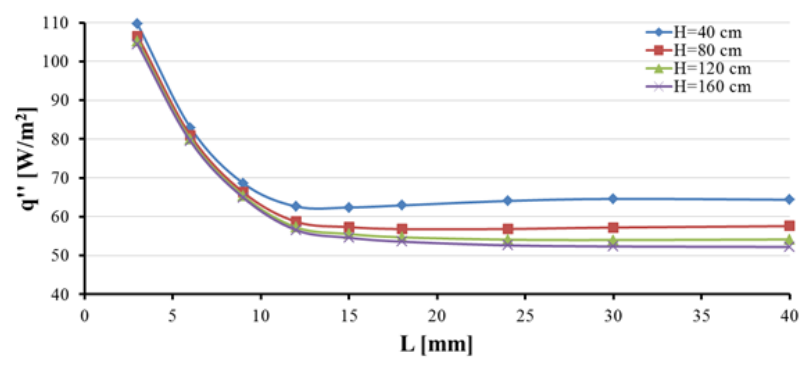

c)Kars

Fig. 11. Average heat flux values versus gap width for various window heights for air filled window

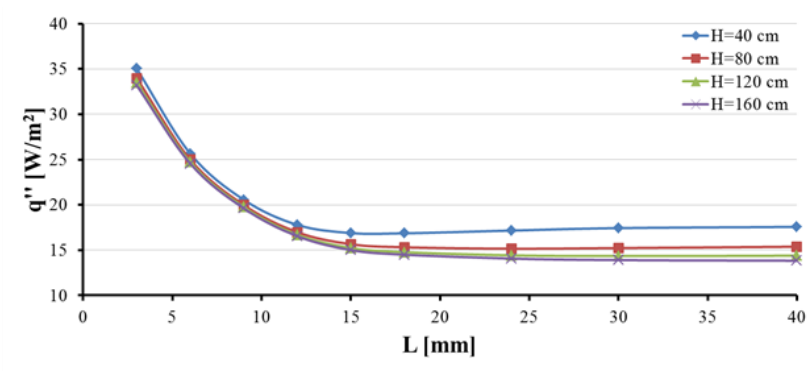

a) Antalya

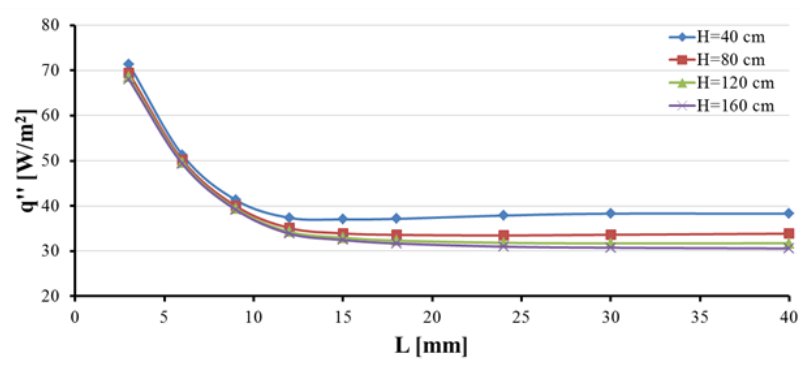

b) Kayseri

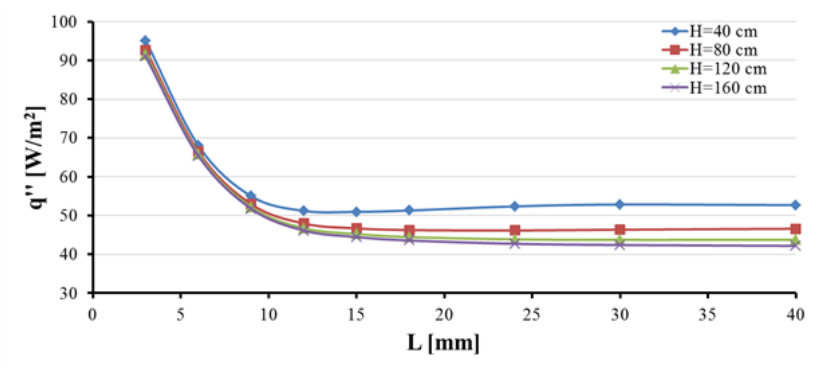

c)Kars

Fig. 12. Average heat flux values versus gap width for various window heights for argon filled window

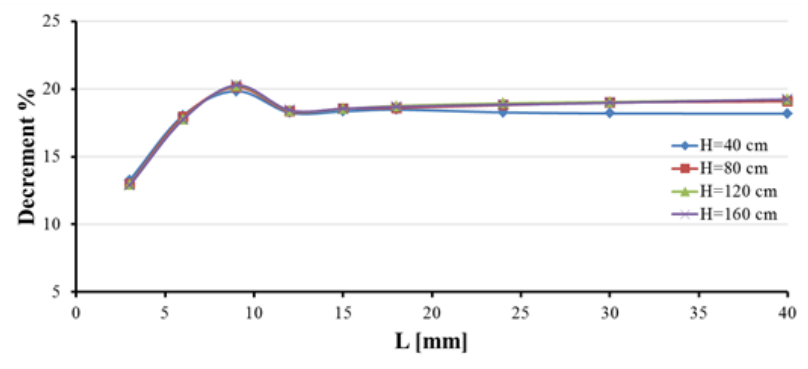

Fig. 13. Comparison of heat flux values versus gap width for argon filled and air filled window for various window heights for Kars city

The Rayleigh Numbers of the gas flow (both air and argon) caused by natural convection in rectangular gas region between two panes for the investigated cases are very important parameters in term of turbulence flow. If $\mathrm{Ra}$ values are above the critical value of $\mathrm{Ra}=1000$ stated in literature for the rectangular cavities of vertical heated and cooled surfaces, the turbulence flow occurs as thin boundary layer and vortex at the vertical hot surface, vertical cold surface and corners of the rectangular cavities [13]. The Rayleigh Numbers for the rectangular gas region between two panes for the investigated cases can be calculated by following equation:

$R a=\frac{2 g(T h-T l) L^{3}}{v \alpha(T h+T l)}$

Where the $\alpha, \mathrm{g}$ and $v$ are thermal diffusivity, gravitational acceleration and kinematic viscosity values of the gas region between two panes. Th and $\mathrm{Tl}$ are avarage temperatures panes surfaces facing the gas region. These parameters can be easily calculated by FLUENT. The calculated $\mathrm{Ra}$ values can be shown in Table 5 for Antalya and Table 6 for Kars cities of the investigated cases. Table 5 and Table 6 indicates that the turbulence effects begins for $\mathrm{L}>9 \mathrm{~mm}$. From this point, assuming the flow turbulent in the numerical solution is correct. Espically, the flow has turbulence for the critical $\mathrm{L}$ values indicating the lowest heat lost. 


\section{Energy, Environment and Storage (2021) 01-01-13-25}

Table 5 The Rayleigh Numbers for gas gap between two panes for Antalya

\begin{tabular}{|c|c|c|c|c|}
\hline \multicolumn{5}{|c|}{ Antalya City } \\
\hline $\mathrm{L}$ & \multicolumn{2}{|c|}{$\mathrm{H}=40 \mathrm{~cm}$} & \multicolumn{2}{|c|}{$\mathrm{H}=160 \mathrm{~cm}$} \\
\hline & Air & Argon & Air & Argon \\
\hline 3 & 19,0 & 26,3 & 16,97 & 25,0 \\
\hline 6 & 210,3 & 294,7 & 201,27 & 2824 \\
\hline 9 & 849,9 & 1153,8 & 821,75 & 1116,6 \\
\hline 12 & 2214,5 & 2942,1 & 2180,01 & 2890,9 \\
\hline 15 & 4506,3 & 5878,8 & 4555,18 & 5902,2 \\
\hline 18 & 7807,7 & 10175,4 & 8041,11 & 10358,1 \\
\hline 24 & 18296,7 & 23932,8 & 19332,22 & 24893,5 \\
\hline 30 & 35451,3 & 46413,8 & 37975,10 & 48758,9 \\
\hline 40 & 83587,2 & 109668,0 & 90157,67 & 116128,0 \\
\hline
\end{tabular}

Table 6 The Rayleigh Numbers for gas gap between two panes for Kars

\begin{tabular}{|c|c|c|c|c|}
\hline \multicolumn{5}{|c|}{ Kars City } \\
\hline $\mathrm{L}$ & \multicolumn{2}{|c|}{$\mathrm{H}=40 \mathrm{~cm}$} & \multicolumn{2}{|c|}{$\mathrm{H}=160 \mathrm{~cm}$} \\
\hline & Air & Argon & Air & Argon \\
\hline 3 & 57,5 & 70,6 & 55,5 & 68,5 \\
\hline 6 & 645,9 & 752,9 & 629,3 & 736,5 \\
\hline 9 & 2515,3 & 2841,7 & 2486,5 & 2823,8 \\
\hline 12 & 6287,6 & 6949,2 & 6379,6 & 7024,6 \\
\hline 15 & 12298,4 & 13591,1 & 12684,0 & 13915,1 \\
\hline 18 & 21164,6 & 23427,4 & 22135,5 & 24235,1 \\
\hline 24 & 49667,7 & 55055,7 & 52865,3 & 57806,8 \\
\hline 30 & 96504,1 & 107113,1 & 103580,5 & 113245,5 \\
\hline 40 & 229282,5 & 254141,9 & 245881,2 & 268826,5 \\
\hline
\end{tabular}

\section{CONCLUSION}

This study is aimed to examine the effects of window height (H) and gas thickness (L) on the fluid flow and heat transfer in double-paned windows for some cities with different climates in Turkey. The cities examined here are Antalya, Kayseri and Kars. The traditional working fluids are air and argon. The parametric calculations are performed for $\mathrm{H}=40$, 80,120 and $160 \mathrm{~cm}$ and $\mathrm{L}=3,6,9,12,15,18,24,30$ and 40 $\mathrm{mm}$. The air and argon are assumed as ideal gas with the atmospheric pressure corresponding to the selected cities altitude values. All thermo-physical properties of the selected gases were calculated as a function of the operation temperature. The numerical calculations were carried out by FLUENT with the natural convection for indoors and forced convection for outdoors boundary conditions. Most important results are summarized as following:
1. The fluid flow in the rectangular region between the panes is formed as one circulation region for all investigated cases and all cities.

2. With the increasing $\mathrm{L}$, the heat flux values decrease for all $\mathrm{H}$ values both for air and argon. While the rapid decreasing occur up to $\mathrm{L} \approx 15 \mathrm{~mm}$, the constant heat flux (asymptotical behavior) or slightly decreasing and increasing on the heat flux exhibited for $\mathrm{L}>15 \mathrm{~mm}$.

3. For $\mathrm{H}<80 \mathrm{~cm}$, the heat flux reach a minimal value at the certain $\mathrm{L}$ values both for air and argon. These critical values are about $\mathrm{L}=16,14$ and $13 \mathrm{~mm}$ for Antalya, Kayseri and Kars city with $\mathrm{H}=40 \mathrm{~cm}$, respectively. For $\mathrm{H}=80 \mathrm{~cm}$, the calculated values are about $20-25 \mathrm{~mm}$. The critical values reached for $\mathrm{H}>80 \mathrm{~cm}$ occurred at the $\mathrm{L}>40 \mathrm{~mm}$.

4. Increasing $\mathrm{H}$ values caused lower heat flux. For Kars city with double-pane filled by air, the heat flux values reached with $\mathrm{L}=40 \mathrm{~mm}$ are about 65,58 and $52 \mathrm{~W} / \mathrm{m} 2$ for $\mathrm{H}=40,80$ and $160 \mathrm{~cm}$, respectively.

5. Filling the gap with argon instead of air caused lower heat flux. The heat flux values with argon decreased between 12-20\% according to those of air for the investigated cities and all cases in terms of energy saving For Kars city, the heat flux values decreased $13 \%$ at $\mathrm{L}=3$ $\mathrm{mm}$ and $19 \%$ at $\mathrm{L}=40 \mathrm{~mm}$ for argon compared with air.

6. The Rayleigh Numbers calculated for natural convection in the gas region between two panes indicates that the turbulence effects begins for $\mathrm{L}>9 \mathrm{~mm}$.

\section{REFERENCES}

[1] O. Aydın Determination of optimum air-layer thickness in double-pane windows, Energy and Buildings, Vol. 32, pp. 303-308, 2000.

[2] O. Aydin (2006) Conjugate heat transfer analysis of double pane windows, Building and Environment, Vol. 41, pp. 109-116.

[3] M. Arıc1, H. Karabay, Determination of optimum thickness of double-glazed Windows for the climatic regions of Turkey, , Energy and Buildings, Vol. 42, pp. 1773-1778, 2010.

[4] H. Karabay, M. Arıc1, Multiple pane window applications in various climatic regions of Turkey, Energy and Buildings, Vol. 45, pp. 67-71, 2012.

[5] M. Arıc1, H. Karabay, M. Kan, Flow and heat transfer in double, triple and quadruple pane windows, Energy and Buildings, Vol. 86, pp. 394-402, 2015.

[6] M. Arıc1, M. Kan, An investigation of flow and conjugate heat transfer in multiple pane windows with respect to gap width, emissivity and gas filling, Renewable Energy, Vol. 75, pp. 249-256, 2015.

[7] B. I. Basok, B. V. Davydenko, S. A. Isaev, S. M. Goncharuk, L. N. Kuzhel, Numerical modeling of heat transfer through a triple-pane window. Journal of Engineering Physics and Thermophysics, Vol. 89, No. 5, pp. 1277-1283, September, 2016. 


\section{Energy, Environment and Storage (2021) 01-01-13-25}

[8] T. Chow, C. Li, Z. Lin, Thermal characteristics of water-flow double-pane window, International Journal of Thermal Sciences, Vol. 50, pp. 140-148, 2011.

[9] T. Chow, C. Li, Z. Lin, The function of solar absorbing window as water-heating device, Building and Environment, Vol. 46, pp. 955-960, 2011.

[10] M. Bhamjee, A. Nurick, D.M. Madyira, An experimentally validated mathematical and CFD model of a supply air window: Forced and natural flow, Energy and Buildings, Vol. 57, pp. 289-301, 2013.

[11] J. Han, L. Lu, H. Yang, Numerical evaluation of the mixed convective heat transfer in a double-pane window integrated with see-through a-Si PV cells with lowe coatings, Applied Energy, Vol. 87, pp. 3431-3437, 2010.
[12] L. De Giorgi, V. Bertola, E. Cafaro, Thermal convection in double glazed windows with structured gap, Energy and Buildings, Vol. 43, pp. 2034-2038, 2011.

[13] V. A. Rabinovich, A. A. Vasserman, V. I. Nedostup, and L. S. Veksler, Thermophysical Properties of Neon, Argon, Crypton, and Xenon [in Russian], Izd. Standartov, Moscow ,1976.

[14] F. Incropera, W. Dewitt, Fundamentals of Heat and Mass Transfer, John Wiley \& Sons, Inc. 2004.

[15] ANSYS®FLUENT, Release 15.0, 2009.

[16] E. ÖZRAHAT. "Numerical Investigation of Double Pane Window Dimensions for Various Gases" Erciyes University, Graduate School of Natural and Applied SciencesM.Sc. Thesis, August 2007 